\title{
PEMBUATAN DAN UJI AKTIVITAS ELEKTROKATALIS KATODA PtCr/C DIRECT METHANOL FUEL CELL (DMFC)
}

\author{
W. W. Purwanto ${ }^{1)}$, Hairuni S.T.(H ${ }^{1)}$, Slamet ${ }^{1)}$, M. Robbi F. ${ }^{1)}$ dan Verina J.W.D ${ }^{2)}$
}

\begin{abstract}
Abstrak
Penambaan krom pada katoda Pt/C bertujuan untuk meningkatkan aktivitas reduksi oksigen dan mengurangi dampak methanol crossover yang terjadi pada DMFC. Penelitian PtCr/C disintesis dengan menggunakan metode poliol. Karakterisasi katalis dilakukan dengan XRF dan aktivitas katalis dianalisis dengan uji setengah sel dan satu sel. Hasil eksperimen uji setengah sel menunjukkan bahwa penambahan krom sebagai logam kedua belum dapat meningkatkan reaksi reduksi oksigen bila dibandingkan Pt/C ketika diuji tanpa kehadiran metanol sedangkan dengan kehadiran metanol 0.5 M aktivitas reduksi oksigen lebih tinggi. Aktivitas $\mathrm{PtCr} / \mathrm{C}$ terbaik ditunjukkan oleh kinerja PtCr dengan komposisi 0.7:0.3 dimana tanpa kehadiran metanol potensial sel mencapai $0.76 \mathrm{~V}$ dan dengan kehadiran metanol 0.5 M mencapai 0.77V. Aktivitas Pt/C tanpa kehadiran metanol mencapai $1.08 \mathrm{~V}$ dan dengan kehadiran metanol menjadi $0.28 \mathrm{~V}$. Pada uji satu sel, aktivitas reduksi oksigen PtCr/C lebih rendah bila dibandingkan Pt murni. Tegangan maksimum PtCr/C sebesar 336$405 \mathrm{mV}$ dan densitas energi maksimum 0.324-2.8 $\mathrm{mW}$. Untuk Pt/C dengan tegangan maksimum sebesar $431 \mathrm{mV}$ dan densitas energi maksimum $4.86 \mathrm{~mW}$. Kinerja PtCr/C terbaik didapatkan pada katalis katoda hasil preparasi PtCr/C 0.8:0.2 yaitu densitas energi maksimum sebesar $2.8 \mathrm{~mW} / \mathrm{cm}^{2}$ pada $182 \mathrm{mV}$ dan $13.12 \mathrm{~mA} / \mathrm{cm}^{2}$.
\end{abstract}

Kata kunci: Direct Methanol Fuel Cell, Methanol Tolerance, Oxygen Reduction Reaction, PtCr/C,Polyol Methode

\section{Pendahuluan}

Fuel Cell merupakan mesin konversi energi kimia secara langsung menjadi energi listrik (Geiger ,2002). Salah satu fuel cell yang giat dikembangkan adalah Direct Methanol Fuel Cell (DMFC) yang dapat beroperasi pada temperatur rendah dan tidak membutuhkan unit reformer dan humidifier. Permasalahan utama pada DMFC adalah adanya kinetic losses, ohmic losses dan yang terutama terjadi pada katoda adalah methanol cross over (Praburham dkk, 2005). Adanya methanol crossover di katoda mengakibatkan penurunan kinerja DMFC akibat terjadinya mixed potensial yang disebabkan berpindahnya metanol dari anoda ke katoda dan oksidasi metanol (Praburham dkk, 2005). Disamping itu mahalnya logam Pt sebagai katalis katoda juga menyebabkan harga elektroda yang tinggi.

Riset ini bertujuan mensintesis katoda bimetal PtCr yang mampu mengurangi efek metanol crossover sehingga dapat meningkatkan kinerja DMFC. Penambahan krom pada logam Pt diharapkan dapat meningkatkan oxygen vacancy yang dapat meningkatkan reduksi oksigen dan mengurangi oksidasi metanol (Salgado, 2005).

\begin{abstract}
Metode Penelitian
Preparasi elektrokatalis $\mathrm{PtCr} / \mathrm{C}$

Preparasi elektrokatalis menggunakan metode poliol reduksi suksesif, menggunakan alkohol sebagai reduktannya (Jiang, 2005). Garam-garam logam klorida yang digunakan terdiri dari $\mathrm{H}_{2} \mathrm{PtCl}_{6} \cdot 6 \mathrm{H}_{2} \mathrm{O}$ (Merck) dan $\mathrm{CrCl}_{2}$ (Wako). PEG 400 digunakan sebagai reduktan pada sintesis $\mathrm{PtCr}$. $\mathrm{CrCl}_{2}$ direduksi terlebih dahulu oleh PEG 400 pada temperatur $220^{\circ} \mathrm{C}$ (Tzitzios, 2005). Kemudian pada campuran ditambahkan garam Pt. Kemudian ditambahkan $\mathrm{NaOH}$ hingga $\mathrm{pH}=12$ untuk menjaga ukuran partikel (Jiang, 2005; Yin, 2002). Larutan koloid kemudian dipanaskan pada temperatur $160^{\circ} \mathrm{C}$ selama 2 jam kemudian ditambahkan karbon (Vulcan XC-72) dengan perbandingan antara katalis dengan karbon 40:60. Campuran yang dihasilkan kemudian diendapkan selama 10 jam, dicuci dengan etanol untuk menghilangkan sisa PEG dan kotoran lain lalu dicuci dengan air destilat untuk menghilangkan $\mathrm{NaCl}$ yang terbentuk (Yin, 2002). Katalis selanjutnya dikeringkan pada suhu $80^{\circ} \mathrm{C}$ dalam kondisi vakum.
\end{abstract}

\section{Karakterisasi katalis}

Katalis dikarakterisasi dengan menggunakan $X$-ray Fluorscenes (XRF) menggunakan JSX-3211

\footnotetext{
1) Sustainable Energy Research Group, Departemen Teknik Kimia Fakultas Teknik Universitas Indonesia 53

Kampus UI, Depok 16424, Indonesia, Telp: 021-7863516, Fax: 021-7863515

Email: widodo@che.ui.edu

2) P3TEK: Pusat Penelitian dan Pengembangan Energi dan Ketenagalistrikan

Departemen Energi dan Sumber Daya Mineral, Cipulir, Jakarta Selatan
} 
Element Analizer untuk mengetahui komposisi katalis biner yang telah dipreparasi.

\section{Uji setengah sel}

Uji setengah sel dilakukan dengan metode Cyclic Voltammetry pada suhu kamar dengan larutan elektrolit $0.5 \mathrm{M} \mathrm{H}_{2} \mathrm{SO}_{4}$ dan campuran $0.5 \mathrm{M} \mathrm{H}_{2} \mathrm{SO}_{4}$ dengan $0,5 \mathrm{M}$ $\mathrm{CH}_{3} \mathrm{OH}$. Ketiga elektroda di atur dalam alat uji setengah sel Potensiostat VersaStat II (Princeton Applied Research). Elektroda kerja yang digunakan adalah kertas karbon yang telah dilapisi katalis. Untuk elektrode pembantu (counter electrode) digunakan Pt. Sedangkan elektrode referensi digunakan Ag/AgCl. Setelah alat terangkai dengan baik dilakukan purging gas $\mathrm{O}_{2}$ selama 120 menit, kemudian dilakukan scan rate sebesar $50 \mathrm{mVs}^{-1}$.

\section{Fabrikasi MEA}

Membrane Electrode Assembly (MEA) di buat dari lapisan carbon cloth, katalis anoda dan katoda serta membran Nafion ${ }^{\circledR}$ 112. Katalis katoda yang digunakan adalah Pt/C komersial (E-TEK). Pembuatan tinta katalis dilakukan dengan melarutkan katalis di dalam air dan larutan nafion yang dilanjutkan dengan pengadukan dengan menggunakan ultrasonic pulverizer. Kemudian tinta katalis dikuaskan pada carbon cloth. Tahapan penyatuan carbon cloth yang telah dilapisi katalis dengan membran dilakukan dengan hot pressing dengan tekanan $180 \mathrm{lb} / \mathrm{in}^{2}$ selama 5-10 menit pada suhu $120^{\circ} \mathrm{C}$.

\section{Uji sel tunggal}

Uji aktivitas elektrokimia sel tunggal (single cell) dilakukan menggunakan DC Electronic Load dengan mengatur nilai resistansi (tahanan) dengan nilai yang bervariasi sehingga didapatkan nilai arus dan potensial sel. Dari data tersebut akan diketahui nilai densitas energi. Kondisi operasi yang digunakan adalah metanol $2 \mathrm{M}$ dengan laju alir $1 \mathrm{~mL} / \mathrm{menit}$ dan kecepatan udara 10mL/menit pada tekanan $100 \mathrm{kPa}$.

\section{Hasil dan Pembahasan \\ Komposisi katalis}

Hasil karakterisasi X-Ray Fluoresence (XRF) dapat ditampilkan pada Tabel 1.

Dari Tabel 1 terlihat bahwa komposisi katalis katoda PtCr yang didesain yaitu 0.9:0.1 ; 0.8:0.2 dan 0.7:.0.3 tidak dapat terpenuhi. Hasil aktual untuk ketiga komposisi tersebut secara berturut-turut adalah sebagai berikut 5.54:1; 2.78:1 dan 2.86:1. Kecuali \% mol Cr untuk komposisi 0.9:0.1 dan 0.8:0.2. Hal itu disebakan oleh Pt yang tidak tereduksi sempurna oleh PEG.

Anomali yang terjadi pada katalis PtCr 0.7:0.3 masih belum diketahui penyebabnya. Diduga PEG hanya mampu mereduksi Cr sebesar 23\%. Hal ini dilihat dari kandungan Cr pada komposisi 0.8:0.2 dan 0.7:0.3. Perlu dilakukan studi selanjutnya untuk mengetahuinya.
Tabel 1. Perbandingan komposisi katalis PtCr XRF dan desain (dalam \% mol)

\begin{tabular}{|c|c|c|c|c|c|c|}
\hline & \multicolumn{2}{|c|}{$\begin{array}{l}\text { Pt-Cr } \\
0.9: 0.1\end{array}$} & \multicolumn{2}{|c|}{$\begin{array}{l}\text { Pt- Cr } \\
0.8: 0.2\end{array}$} & \multicolumn{2}{|l|}{$\begin{array}{l}\text { Pt- Cr } \\
0.7: 0.3\end{array}$} \\
\hline & $\% w t$ & $\% \mathrm{~mol}$ & $\%$ wt & $\% \mathrm{wt}$ & $\% \mathrm{wt}$ & $\% \mathrm{~mol}$ \\
\hline $\mathrm{Pt}$ & 88.8 & 69.65 & 88.8 & 64.10 & 89.58 & 66.78 \\
\hline $\mathrm{Cr}$ & 4.27 & 12.57 & 8.5 & 23.03 & 8.35 & 23.34 \\
\hline $\mathrm{Na}$ & - & - & - & - & - & - \\
\hline $\mathrm{Cl}$ & - & - & - & - & - & - \\
\hline $\mathrm{NaCl}$ & 5.91 & 15.47 & - & - & - & - \\
\hline $\mathrm{Fe}$ & 0.28 & 0.78 & 0.17 & 0.44 & 0.34 & 0.88 \\
\hline $\mathrm{Zn}$ & 0.65 & 1.5 & - & - & - & - \\
\hline $\mathrm{Si}$ & - & - & 2.47 & 0.124 & 1.737 & 8.99 \\
\hline
\end{tabular}

Uji Aktivitas Elektrokimia Setengah Sel Perbandingan CV Pt/C dengan PtCr/C (variasi komposisi)

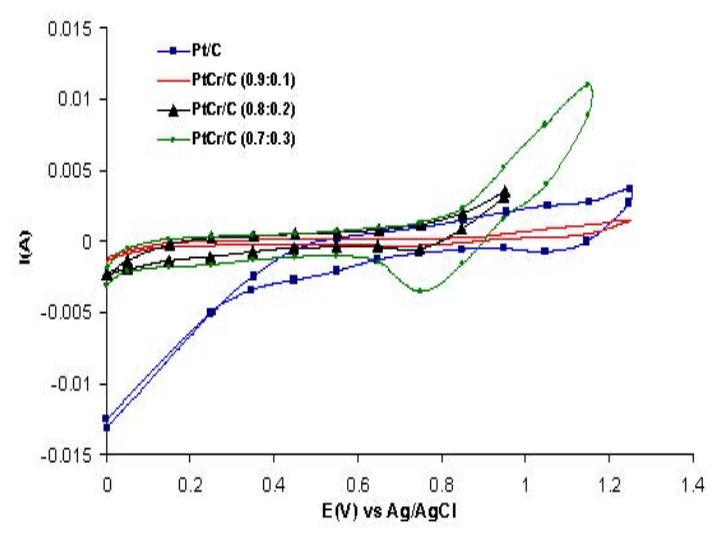

Gambar 1. CV Pt/C dan PtCr/C dengan elektrolit $0.5 \mathrm{M} \mathrm{H}_{2} \mathrm{SO}_{4}$

Pada Gambar 1 terlihat aktivitas reduksi oksigen elektrokatalis $\mathrm{Pt} / \mathrm{C}$ lebih besar dari semua elektrokatalis $\mathrm{PtCr} / \mathrm{C}$, besarnya berturut - turut untuk Pt/C, Pt:Cr (0.9:0.1), (0.8:0.2) dan (0.7:0.3) adalah $1.08 \mathrm{~V}, 0.74 \mathrm{~V}, 0.73 \mathrm{~V}$, dan $0.76 \mathrm{~V}$. Hasil yang berbeda didapatkan oleh Hui Yang dkk [Yang, 2005] hasil aktivitas reduksi oksigen $\mathrm{PtCr} / \mathrm{C}$ lebih besar dari Pt/C dengan metode sintesis menggunakan senyawa karbonil. Perbedaan ini disebabkan karena elektrokatalis $\mathrm{PtCr} / \mathrm{C}$ yang dihasilkan dengan metode polyol belum berbentuk alloy sehingga $\mathrm{Cr}$ hanya menempel pada permukaan Pt aktivitas reduksi menjadi lebih kecil karena loading Pt lebih rendah. Tidak terbentuknya alloy disebabkan karena proses reduksi kedua logam dilakukan terpisah. 
Perbandingan CV PtCr/C tanpa dan adanya metanol

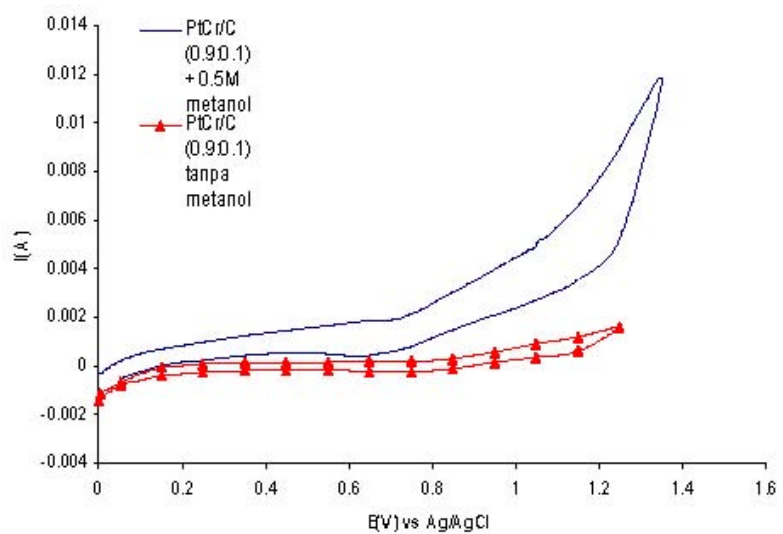

(a)

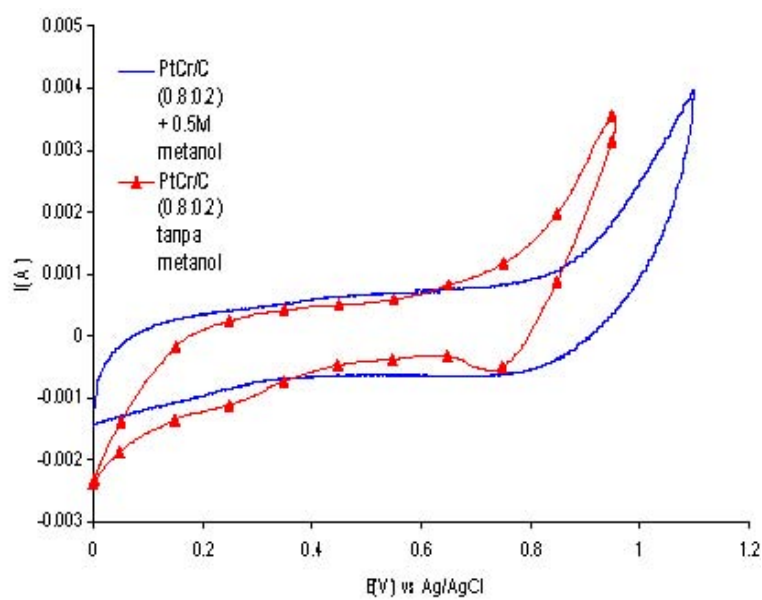

(b)

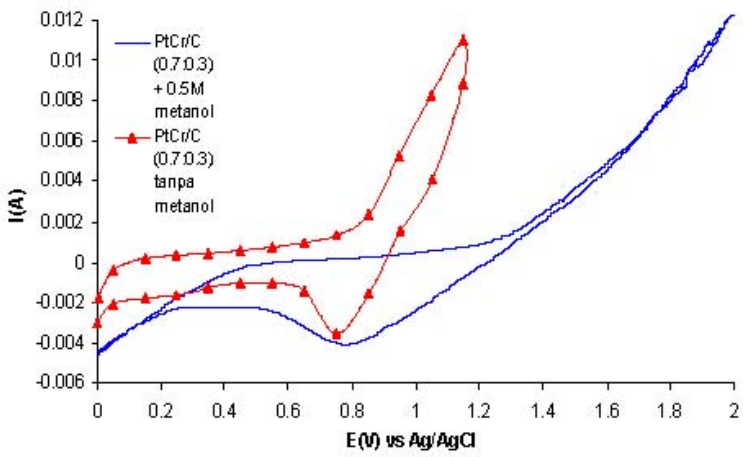

(c)

Gambar 2. Cyclic Voltammogram PtCr/C pada elektrolit $0.5 \mathrm{M} \mathrm{H}_{2} \mathrm{SO}_{4}$ dan $\mathrm{PtCr} / \mathrm{C}$ pada elektrolit $(0.5 \mathrm{M}$ $\mathrm{H}_{2} \mathrm{SO}_{4}+0.5 \mathrm{M}$ metanol) scan rate $50 \mathrm{mVs}^{-1}$ a. (0.9:0.1) ; b. $(0.8: 0.2)$ dan c. $(0.7: 0.3)$

Gambar 2 menunjukkan peak potensial reduksi oksigen $\mathrm{PtCr} / \mathrm{C}$ dengan adanya metanol lebih kecil dibandingkan dengan tanpa metanol. Tetapi penurunan yang terjadi tidak terlalu besar seperti yang terjadi pada $\mathrm{Pt} / \mathrm{C}$. Peak potensial reduksi tanpa metanol untuk komposisi (0.9:0.1), (0.8:0.2) dan (0.7:0.3) berturut- turut sebesar $0.74 \mathrm{~V}, 0.73 \mathrm{~V}$ dan $0.76 \mathrm{~V}$ sedangkan dengan adanya metanol sebesar $0.63 \mathrm{~V}, 0.7 \mathrm{~V}$ dan 0.77V. Hal ini membuktikan bahwa adanya Cr dalam elektrokatalis menyebabkan elektrokatalis lebih toleran terhadap metanol. Ketahanan elektrokatalis $\mathrm{PtCr} / \mathrm{C}$ terhadap metanol disebabkan karena terjadi kompetisi adsorpsi oksigen dan metanol pada permukaan elektrokatalis.

\section{Uji aktivitas elektrokimia sel tunggal}

Untuk melihat pengaruh penambahan logam Cr terhadap keaktifan katalis, maka akan dibandingkan hasil uji aktivitas elektrokimia sel tunggal katalis katoda bimetal PtCr dan katalis katoda Pt. Hasil perbandingan ini ditunjukkan oleh Gambar 3 dan Gambar 4 untuk PtCr.

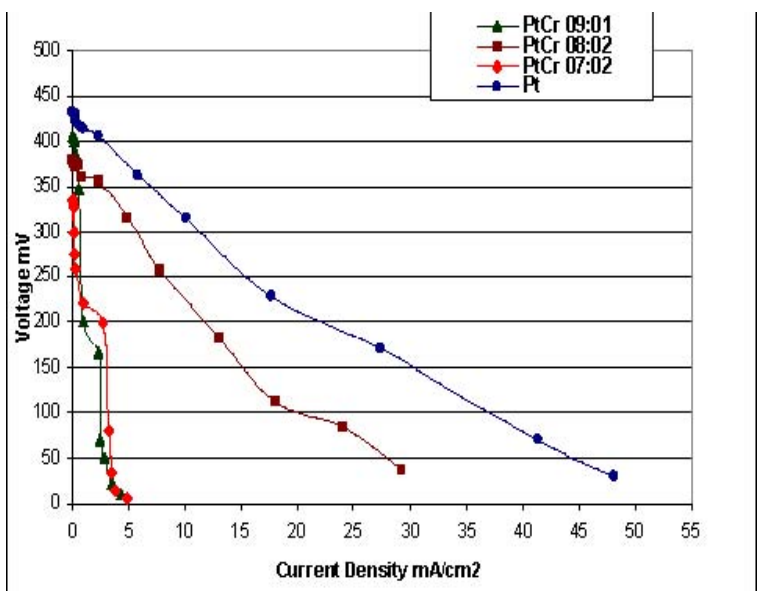

Gambar 3. Kurva polarisasi perbandingan potensial sel antara katalis katoda Pt ; PtCr komposisi 0.9:0.1 ; 0.8:0.2 dan 0.7:0.3 pada temperatur $70^{\circ} \mathrm{C}$

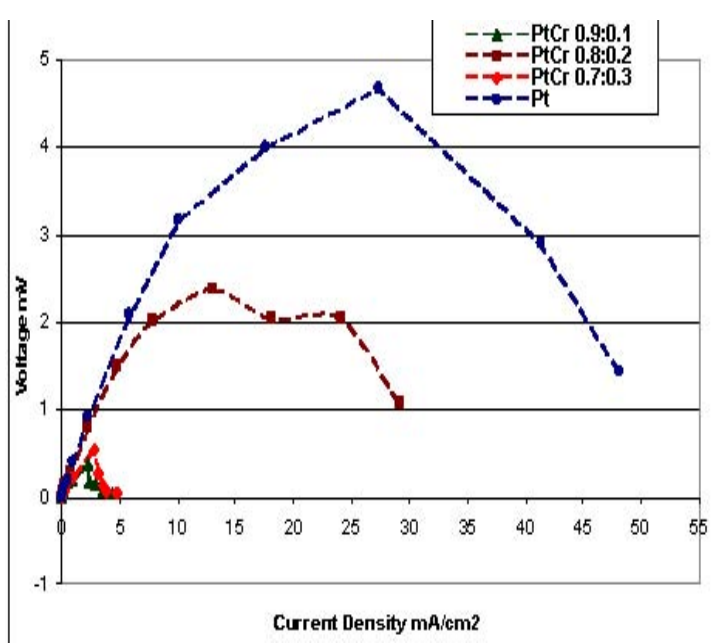

Gambar 4. Kurva polarisasi perbandingan densitas energi antara katalis katoda PtCr komposisi 0.9:0.1 ; 0.8:0.2 dan 0.7:0.3 pada temperatur $70^{\circ} \mathrm{C}$

Gambar 3 menunjukkan komposisi katalis 
PtCr 0.9:0.1 memiliki potensial sel yang lebih tinggi dibanding PtCr 0.8:0.2 dan 0.7:0.3. Namun PtCr 0.8:0.2 memiliki densitas arus dan densitas energi yang lebih besar dibandingkan katalis PtCr lainnya. Dikarenakan potensial sel Pt tetap lebih tinggi dibandingkan ketiga katalis $\mathrm{PtCr}$ maka dapat disimpulkan bahwa penambahan $\mathrm{Cr}$ tidak dapat meningkatkan reaksi reduksi oksigen.

\section{Kesimpulan}

Berdasarkan diskusi diatas dapat disimpulkan bahwa penambahan krom memberikan ketahanan terhadap kehadiran metanol namun belum dapat meningkatkan reduksi oksigen. Hal ini disebabkan katalis yang disintesis belum membentuk alloy sehingga belum dapat membentuk oxygen vacancy yang dapat meningkatkan reduksi oksigen.

\section{Ucapan Terimakasih}

Penulis mengucapkan terimakasih kepada Kementrian Negara Riset dan Teknologi (KNRT) atas dana penelitian melalui Riset Unggulan Terpadu (RUT) XII.

\section{Daftar Pustaka}

Geiger A., (2002), “Characterization and Development of Direct Methanol Fuel Cells”, Dissertation, Institute of Technology Zurich, Swiss.
Jiang, Luhua dkk., (2005), "Structure and Chemical Composition of Supported Pt-Sn Electrocatalysts for Ethanol Oxidation”, J. Electrochimica Acta, 50, hal. 5384-5389.

Praburham J., dkk., (2005), "Methanol adsorbates on the DMFC cathode and their effect on the cell performance", Journal of Electroanalytical Chemistry, 578, hal.105-112.

Salgado, J. R. C dkk,. (2005), “Carbon supported PtCo alloys as methanol-resistant oxygen-reduction electrocatalysts for direct methanol fuel cells”, $J$. Applied catalysis B: Environmental 57, 283-290.

Tzitzios, V. dkk, (2005), "Synthesis of PtCo Nanoparticles by a Modified Polyol Method : Characterizationand Magnetic Properties”, Institute of Physics Publishing Nanotechnology,16,hal 287291.

Yang, Hui dkk. (2005), "High Methanol Tolerance of Carbon-Supported Pt-Cr Alloy nanoparticle Electrocatalysts for Oxygen Reduction”, Journal of The Electrochemical Society,152,hal A704-A709.

Yin H., Chow G.M, (2002), “Anomalous Electroless Polyol Deposition of FeNi Powders and Films”, J. Electrochem Soc., 149, hal C68-C73 . 